\title{
Impact of Chiapanecan Handicrafts
}

\author{
Karla Liliana Haro-Zea \\ Meritorious Autonomous University of Puebla, Mexico \\ Karla S. Basurto Gutiérrez \\ University of Montemorelos, Mexico \\ Blanca H. Morales Vázquez \\ Meritorious Autonomous University of Puebla, Mexico \\ Omar A. Flores Laguna \\ University of Montemorelos, Mexico
}

\begin{abstract}
The purpose of this research is to study the perception of Chiapanecan handicrafts as an element of sustainable competitive advantage in the State of Chiapas, Mexico, mainly due to the tourism. Mexican handicrafts contribute to $20.3 \%$ of the Gross Domestic Product (GDP) of the cultural sector, that is, $0.6 \%$ of the National GDP. This research is quantitative, descriptive, and transversal. The sample selection was made for convenience so certain criteria could be met. In total, 70 tourists were surveyed in the handicraft commerce area. For the data retrieval, an instrument with the "Sustainability SWOT" (sSWOT) was designed, which consists of eight dimensions (trends, environmental challenges, threats, opportunities, strengths, weaknesses, which to prioritize, and where to act). The instrument consists of 22 items with a single Likert scale ranging from 1 to 5 ( 1 = Null to $5=$ Excellent). The study showed that $54.29 \%$ of the tourists who visit Chiapas perceive that handicrafts have a regular impact on the small producer's quality of life, while the remaining $45.71 \%$ point out that the impact is greater.
\end{abstract}

Keywords: strategy, competitiveness, handicrafts, competitive advantage, sustainability and innovation

\section{Introduction}

In the words of Stronza (2001), tourism can be an ideal context for studying issues of political economics, social change and development, natural resource management, as well as cultural identity and expression. The presented work centers on the perception of the tourists, Mexico receives around 25.57 million of tourists and an average of 14.3 million dollars in foreign currency due to international tourism each year (World Tourism Organization, 2016). It is highlighted that in 2015, the touristic affluence in Chiapas was situated in 5.2 million visitors, with a sleepover rate of 2.3 nights for the national visitor and 3.4 nights for an international visitor. Tourism in Chiapas has been growing at an annual rate of $12 \%$, well above the national median (9\%) and at twice the international median, which is situated around $4.5 \%$. This is an industry that generates 55,000 direct jobs, almost 7\% of the local GDP (El Economista, 2016).

Karla L. Haro-Zea, Fulltime Research Professor, Facultad de Contaduría Pública, Meritorious Autonomous University of Puebla. Email: kharozea@gmail.com.

Karla S. Basurto Gutiérrez, Graduated Professor, Facultad de Ciencias Empresariales y Juridicas, University of Montemorelos. Blanca H. Morales Vazquez, Fulltime Professor, Facultad de Contaduría Pública, Meritorious Autonomous University of Puebla.

Omar A. Flores Laguna, Director of the Research Department for Business, Facultad de Ciencias Empresariales y Juridicas, University of Montemorelos. 
Towards 2016, Chiapas received 5,616,972 tourists, which left an economic revenue of 18,782,000,000 Mexican pesos. When it comes to diverse offers, the state is home to a plethora of choices of hotels, transportation services and gastronomic options, which is shown with its vast total of 983 hotels spread amongst the city of San Cristobal de las Casas, Tuxtla Gutierrez, Palenque, Tapachula, Tonala, Comitan de Dominguez and Chiapa de Corzo. Chiapas boasts with 1,413 restaurants, 176 travel agencies, 15 car rental companies and 45 touristic transport companies (Unión Chiapas, 2017).

The State of Chiapas is both nationally and internationally recognized for being a cultural tourism destination and therefore it is the place where more handicrafts are commercialized, within the towns that are highlighted with the greatest affluence of cultural tourism which are Tuxtla Gutierrez, San Cristobal de las Casas, Palenque, Comitan de Dominguez and Chiapa de Corzo.

According to the Tourism Satellite Account of Mexico (TSAM), in the year 2014, handicrafts contributed to 20.3\% of culture sector GDP, which represents $0.6 \%$ of the National GDP (National Institute of Statistics and Geography \& Secretariat of Culture, 2012). This way, it is possible to affirm that handicrafts do in fact have an important impact on both tourism indicators and culture indicators. Handicrafts being an intangible heritage of the State of Chiapas that represents both culture and traditions, it is the commercialization of these a central element in the competitive advantage of the cultural tourism in the state.

\section{Contribution and Benefits of the Study}

Handicrafts and traditional toys making are the biggest production activities within the culture sector in Mexico, the activities that make up this sector such as ceramics, textiles, pottery, basket making, woodwork, metalwork, headstone making, stonework, glasswork, waxwork, cardboard and paper work, leatherwork, and even traditional candies 91,612 million pesos of GDP in 2014, which creates more revenue than the scenic arts, shows, fine arts and editorial industry put together. In the same year, the TSAM reported that 339,349 paid jobs had been generated, these are 8 hour day work shifts, which is not comparable to the number of people working. This is, three out of every 10 positions taken in the cultural sector correspond to handicrafts (National Institute of Statistics and Geography \& Secretariat of Culture, 2012), where the importance of this research lies.

The following research has as an objective to know the perception that the tourists have on Chiapanecan handicrafts as an element of sustainable competitive advantage in the State of Chiapas.

This research is organized in the following manner: the next section is a revision of literature that has allowed contextualizing of the competitive advantage of handicrafts, subsequently the methodology is noted, and lastly, both results and conclusions are presented.

\section{Theoretical Framework}

\section{Nature of Handicrafts}

According to the United Nations Educational, Scientific and Cultural Organization (UNESCO, 2017), handicrafts are an artistic expression rooted in community traditions. They pass on knowledge from one generation to the next, often orally, and thus they are part of an intangible heritage. Contemporary handicrafts also exist alongside creative industries. As people are open to acquiring objects of symbolic value, crafts have managed to adapt in new ways, creating innovative products that reflect the creativity and cultural heritage of their creators. 
For the Export Promotion Council for Handicrafts (2011), handicrafts may be defined as items or products produced through skills that are manual, with or without mechanical or electrical or other processes which appeal to the eye, due to characteristics of being artistic or aesthetic or creative or ethnic or being representative of cultural or religious or social symbols or practices, whether traditional or contemporary. These items or products may, may not have a functional utility, or can be used as a decorative item or gift.

Another vision is the one raised by Abryareh (2009) and De Silver and Kundu (2013) in that handicrafts are a type of work where a useful and decorative device is made completely by hand or using only simple tools, with individual crafter's cultural and/or religion a paramount criterion. Handicrafts are made based on local and traditional techniques and can be produced in both rural and urban environments, and it should also be noted that handicrafts are affected by the natural environment (Afrakhte, 2014).

Additionally, Dominique (2008) stated that as an opposition to globalization of culture, in a way to live and lifestyles, some expect items with roots, things loaded with history, with an identity, characterized by its origin, as well as the artist that created it, or for the materials that were used in the making of said item. Aside from the global objective, a wide market exists for local items. In addition to anonymous production, there is a vast production of items with their own identity.

Therefore, handicrafts do not answer to a single closed and defined concept. Their extraordinary capacity to express ideas and transmit emotions on such a small scale, with limited resources, allows the development of a fresh creativity, spontaneous and diverse, adapted to the different ways different social groups think. This is the reason why there are different concepts of handicrafts and why these tend to evolve in the times of social change (Santos, 2008).

Rodríguez (2002) expressed that handicraft is often understood as an activity restricted to a local environment that is not integrated in the general production dynamic or as labor that is complimentary to the tourism offer of some of the territories. Nonetheless, in the State of Chiapas, a place recognized for its cultural tourism, handicrafts are not a complimentary element but an indispensible element to achieve competitive advantage.

\section{Chiapanecan Handicrafts as a Competitive Advantage}

Competitive advantage has been defined in numerous ways, but a simple definition is that a competitive advantage exists when a firm has generated above-normal returns (or economic value) relative to its competitors (Peteraf \& Barney, 2003).

Competitive advantage is the degree to which a firm is able to gain and retain a leading position over its competitors through creating value for its customers (Feng, Sun, \& Zhang, 2010; Porter, 1980).

According to Sánchez, Vargas, Mejía, Vázquez, and Gaytán (2013), competitiveness has become a key condition for sustaining and growing in highly globalized and competitive markets.

Furthermore, Ployhart and Donald (2014) noted that competitive advantage is inherently a comparative, between-firm metric based on standing relative to other firms. Not simply profit, revenue, or growth, competitive advantage is about generating above-normal or supernormal returns. Thus, competitive advantage occurs between firms and emphasizes generating above-normal returns via differentiation from competitors.

Thus, the competitiveness encompasses capabilities that enable a firm to distinguish itself from its competitors and is an outcome of strategic management decisions (Tracey, Vonderembse, \& Lim, 1999). 
Other authors state that, in the rationale of competitive marketing, valuing authenticity and the constancy of local traditions put cultural organizations at a disadvantage. Thus, the idea of preserving local traditions versus competitiveness seems contradictory. Yet, they are not contradictory. Authenticity - what is valuable about a cultural product - is related to the originality that only cultural organizations can offer (Cappetta, Manzoni, \& Salvemini, 2010).

Resuming on Porter (1990), national prosperity is created not inherited, as competitiveness depends on the capacity of the industries' ability to innovate and improve, only then it is possible to note if the handicraft activity comes from knowledge that has been handed down generation from generation. Also, it is an activity that evolves with time to be able to compete and be sustainable in the market. Consequently, the artisans' job little by little has been innovating, mixing the best of their creations in embroidery and textiles with other materials.

It can be noted in Table 1 that in Chiapas as well as Mexico in general, there are many handicraft branches and it is an activity in which both men and women partake.

Table 1

Handicraft Branches and It is an Activity in Which Both Men and Women Partake

\begin{tabular}{lrrr}
\hline Handicraft branches & \multicolumn{1}{c}{ Men } & \multicolumn{1}{c}{ Women } & \multicolumn{1}{c}{ Total } \\
\hline Cardboard and paper & $1,031,525$ & $1,954,712$ & $2,986,237$ \\
Ceramics or pottery & 48,197 & 128,027 & 176,224 \\
Basket making & 20,792 & 125,347 & 146,139 \\
Sculpting & 102,336 & 104,179 & 206,515 \\
Varnishing & 31,399 & 33,431 & 64,830 \\
Woodwork & 630,165 & 352,650 & 982,815 \\
Metalwork & 173,346 & 75,577 & 248,923 \\
Other & 58,125 & 111,844 & 169,969 \\
Popular painting & 239,104 & 431,627 & 670,731 \\
Textiles & 208,198 & $1,530,475$ & $1,738,673$ \\
Glassmaking & 90,525 & 52,362 & 142,887 \\
Total & $2,633,712$ & $4,900,231$ & $7,533,943$ \\
\hline
\end{tabular}

The Chiapanecan handicrafts are as diverse that they clearly can be distinguished not only amongst themselves, but also amongst the rest of other Mexican handicrafts as well as others around the world, a characteristic that makes them very attractive. Additionally, these handicrafts stand out due to their colorful unique designs as well as textures, in which they reflect the culture and customs of each region from where they originate.

It is possible to point out that handicraft from Chiapas due to the materials and processes that it uses has a sustainable competitive advantage, everytime textiles, and handmade embroidery, hand carvings done in deadwood, as well as commercialization of amber pieces, these are materials that do not have a negative impact on the environment and wood carving is mainly done on pieces of dead wood.

\section{Methodological Aspects}

The purpose of this research was to know the perception of tourists who visit the State of Chiapas, Mexico, specifically the cities of Tuxtla Gutiérrez, San Cristóbal de las Casas and Chiapa de Corzo where a great variety of regional handicrafts are made. The research was empirical, quantitative, descriptive, and transversal. In order to analyze the impact of the Chiapanecan handicrafts, a descriptive study was made from the survey results. 


\section{Sample}

The population that was used for this research consists of the tourists that were found buying some handicraft in Tuxtla Gutierrez, San Cristobal and Chiapa de Corzo. These places were chosen considering that these are the most visited as well as these places are hubs for artisans who wish to sell their handicrafts. For this research, a convenience sample of 70 tourists. For the data recollection, an instrument based on the "Sustainability SWOT" (sSWOT) was made, which consists of eight constructs (tendencies, environmental challenges, threats, opportunities, strengths, weaknesses, which strategies to prioritize, and where to act) as well as 22 indicators.

In Table 2, the results referring to the surveyed tourists' gender are shown: $47.1 \%$ are of the female gender and $52.9 \%$ are of the male gender.

Table 2

Gender of Surveyed Tourists

\begin{tabular}{llc}
\hline Gender & $f$ & $\%$ \\
\hline Female & 33 & 47.1 \\
Male & 37 & 52.9 \\
Total & 70 & 100.0 \\
\hline
\end{tabular}

In Table 3, the results referring to the age of surveyed tourists are shown: $25.7 \%$ aged $15-25 \mathrm{y} / 0,27.2 \%$ aged 26-35 y/o, 21.4\% aged 36-45 y/o, 14.3\% aged 46-55 y/o, and 11.4\% aged 56 and older.

Table 3

Age of Surveyed Tourists

\begin{tabular}{lcc}
\hline Age & $f$ & $\%$ \\
\hline $15-25$ & 18 & 25.7 \\
$26-35$ & 19 & 27.2 \\
$36-45$ & 15 & 21.4 \\
$46-55$ & 10 & 14.3 \\
56 and older & 8 & 11.4 \\
Total & 70 & 100.0 \\
\hline
\end{tabular}

In Table 4, the referred results of the places where the samples of surveyed tourists were taken are shown: 14.2\% Tuxtla Gutierrez, 42.9\% Chiapa de Corzo, and 42.9\% San Cristobal de las Casas.

Table 4

Places Where Tourists Were Surveyed

\begin{tabular}{llc}
\hline Place & $f$ & $\%$ \\
\hline Tuxtla Gutierrez & 10 & 14.2 \\
Chiapa de Corzo & 30 & 42.9 \\
San Cristobal de las Casas & 30 & 42.9 \\
Total & 70 & 100.0 \\
\hline
\end{tabular}

\section{Data Collection Tool}

The instruments were evaluated using a Likert scale ranging from 1 to 5 ( $1=$ Null to $5=$ Excellent $)$. This scale notes the perception of the tourists over the handicrafts produced in Chiapas. 


\section{Data Analysis}

In Table 5, the perceptions that the tourists have over the tendencies of handicrafts made from Chiapas are listed.

Table 5

Perception of the Market Tendencies

\begin{tabular}{lrc}
\hline & $f$ & $\%$ \\
\hline Null & 0 & 0 \\
Low & 4 & 5.71 \\
Regular & 24 & 34.29 \\
Good & 34 & 48.57 \\
Excellent & 8 & 11.43 \\
Total & 70 & 100 \\
\hline
\end{tabular}

In Table 6, the perception that the tourists have over the environmental challenges that are faced by the handicraft production can be observed, where $70 \%$ of the surveyed consider that the challenges are positioned between regular and good, although $25.71 \%$ consider them to be low.

Table 6

Perception of the Environmental Challenges

\begin{tabular}{lcc}
\hline & $f$ & $\%$ \\
\hline Null & 0 & 0 \\
Low & 18 & 25.71 \\
Regular & 26 & 37.14 \\
Good & 23 & 32.86 \\
Excellent & 3 & 4.29 \\
Total & 70 & 100 \\
\hline
\end{tabular}

Table 7 shows that $40 \%$ of the tourists perceive that the market opportunities for this industry are good and 27.14\% consider them to be excellent.

Table 7

Perception of the Market Opportunities

\begin{tabular}{lcc}
\hline & $f$ & $\%$ \\
\hline Null & 6 & 8.57 \\
Low & 6 & 8.57 \\
Regular & 11 & 15.72 \\
Good & 28 & 40.00 \\
Excellent & 19 & 27.14 \\
Total & 70 & 100 \\
\hline
\end{tabular}

Table 8 shows the perception of strengths that tourists have towards the chiapanecan handicraft, where $85.72 \%$ of the tourists consider that they are between good and excellent. 
Table 8

Perception of Strengths

\begin{tabular}{lcc}
\hline & $f$ & $\%$ \\
\hline Null & 4 & 5.71 \\
Low & 1 & 1.43 \\
Regular & 5 & 7.14 \\
Good & 25 & 35.72 \\
Excellent & 35 & 50.00 \\
Total & 70 & 100 \\
\hline
\end{tabular}

Table 9 shows the perception that tourists have towards the weaknesses of the Chiapanecan and $75.72 \%$ of the tourists consider that they are null, low and regular.

Table 9

Perception of Weaknesses

\begin{tabular}{lrc}
\hline & $f$ & $\%$ \\
\hline Null & 4 & 5.71 \\
Low & 18 & 25.72 \\
Regular & 31 & 44.29 \\
Good & 13 & 18.57 \\
Excellent & 4 & 5.71 \\
Total & 70 & 100 \\
\hline
\end{tabular}

Table 10 shows the perception of tourists over the strategies that need to be prioritized in order that Chiapanecan handicraft can be consolidated as an element of sustainable competitive advantage in the State of Chiapas and the other $67.14 \%$ of the tourists consider it to be among regular and good.

Table 10

Perception of Strategies That Need to be Prioritized

\begin{tabular}{lcc}
\hline & $f$ & $\%$ \\
\hline Null & 1 & 1.43 \\
Low & 9 & 12.86 \\
Regular & 18 & 25.71 \\
Good & 29 & 41.43 \\
Excellent & 13 & 18.57 \\
Total & 70 & 100 \\
\hline
\end{tabular}

Table 11 shows the perception of tourists over the strategies that need to be carried out in order to promote Chiapanecan handicrafts where $55.72 \%$ note that it is around good and excellent.

Table 11

Perception of Strategies for the Development of the Handicrafts

\begin{tabular}{lcc}
\hline & $f$ & $\%$ \\
\hline Null & 6 & 8.57 \\
Low & 13 & 18.57 \\
Regular & 12 & 17.14 \\
Good & 18 & 25.72 \\
Excellent & 21 & 30.00 \\
Total & 70 & 100 \\
\hline
\end{tabular}


Table 12 shows the impact of Chiapanecan handicrafts from the perspective of the tourists who visit Chiapas. As seen from the table, $54.29 \%$ of the tourists note that the impact is regular, while the remaining $45.71 \%$ consider the impact to be good.

Table 12

Impact of Chiapanecan Handicrafts

\begin{tabular}{lrc}
\hline & $f$ & $\%$ \\
\hline Null impact & 0 & 0 \\
Low impact & 0 & 0 \\
Regular impact & 38 & 54.29 \\
Good impact & 32 & 45.71 \\
High impact & 0 & 0 \\
Total & 70 & 100 \\
\hline
\end{tabular}

\section{Discussion}

It can be noted that the majority of surveyed tourists are male in gender and are aged between 15 to 45 years of age.

The surveyed tourists were located in the following towns: $14.2 \%$ in Tuxtla Gutierrez, $42.9 \%$ in Chiapa de Corzo, and 42.9\% in San Cristobal de las Casas. These places were chosen due to their cultural tourism, hence Tuxtla Gutierrez is visited primarily because of the Catedral de San Marcos, Parque de la Marimba, Regional Museum of Anthropology and History of Chiapas, Miguel Alvarez del Toro Zoo and Cañon del Sumidero which is located between Tuxtla Gutierrez and Chiapa de Corzo, the latter is considered by many to be the base of the cultural identity of the State of Chiapas. It was one of the first founded towns by the Castillians in the Chiapanecan land. Chiapa de Corzo is located $14 \mathrm{~km}$ from Tuxtla Gutierrez and $62 \mathrm{~km}$ from San Cristobal de las Casas; this beautiful place has great richness in both flora and fauna. Currently, Chiapa de Corzo inserts itself in the zone of national and historical landmarks; this was stated in the Official Journal of the Federation on November 24 in the year 2000 (Mexico Destinos, 2017).

San Cristobal de las Casas has also been called by many tourists, one of the most romantic towns in the world, acknowledged as a Magical Town whose richness lies in its ethnic diversity and colonial tradition, which shows its architectural treasures in diverse buildings, which were conceived in the 16th, 17th, and 18th centuries (Turismo Chiapas, 2017).

It is noted that $82.86 \%$ of the tourists perceive that Chiapanecan handicraft tendencies are among regular and good. At the same time, $40 \%$ consider the market opportunities to be good and $27.14 \%$ consider it to be excellent, which means an area of opportunity for artisanal production, in other words without losing its essence, as well as working more towards the innovation for local, regional, and international consumption of the goods.

As for environmental challenges in the artisanal production, $70 \%$ of the surveyed considered that they are between regular and good, although $25.71 \%$ consider it to be low. In this sense, it should be highlighted that artisanal activities in the three towns, which were subjected to the study textiles, hand embroidery, deadwood carvings, sale of amber pieces and varnishing have no negative impact on nature.

Considering tourists' perceptions towards the strengths and weaknesses of the Chiapanecan, $85.72 \%$ consider that strengths predominate in Chiapanecan handicrafts, while $75.72 \%$ of the tourists consider that weaknesses are null, low, and regular. 
In addition, $67.14 \%$ of tourists consider the strategies that need to be prioritized in order that Chiapanecan handicraft can be consolidated as an element of sustainable competitive advantage in the State of Chiapas to be between regular and good, while $55.72 \%$ of the tourists perceive the strategies that are being implemented in order to promote Chiapanecan handicrafts to be between good and excellent, meaning that strategies should not be focused only in looking for promoting the handicrafts but at the same time making a local impact.

Considering the impact of Chiapanecan handicrafts, $54.29 \%$ of the tourists who visit Chiapas note that their handicrafts impact the quality of life of the small producers in a regular way, while $45.71 \%$ note that the impact is good. It is important to remember that according to the statistics published by the TSAM, handicrafts have an important impact on the indicators of Tourism \& Culture, but the most important thing would be that these impact the quality of life of the local producers.

\section{Conclusions}

Handcrafting is a noble activity due to the materials and processes not having a negative impact on the environment as well as three out of every 10 jobs in the cultural sector correspond to handcrafting; nonetheless, an important impact on the quality of life of the local producers cannot be perceived.

Handicrafts have been adapting to changes in the market but areas of opportunity exist in terms of designs that could help penetrate other markets.

The nature of the handicrafts allows artisans to have a sustainable competitive advantage due to it being handed down generation-to-generation, as well as creativity being present, different ways of thinking, cultures, traditions, emotions, and the feelings of their creators.

The State of Chiapas is a place known for its cultural tourism, and in this case, handicrafts are not a complimentary element of tourism but an indispensible element to achieve a competitive advantage for the destination.

The effort that is exerted in order to promote Chiapanecan handicrafts is admirable but certainly not enough to develop the artisanal activity. It is necessary to implement strategies with a local, regional, national, and even global vision.

\section{Future Research}

This is a study of the perception of tourists who travel to Chiapas over the sustainable competitive advantage of the handicrafts, which are made in the State, but handicrafts have a vast scope of opportunities for possible research. According to the culture indicators in Mexico alone, it is possible to identify 11 artisanal branches. Nonetheless, some branches are not identified as part of the identity of each place, consequently leaving an opening for new lines of research. Furthermore, different focuses can be given besides the already existing ones.

\section{References}

Abryareh, R. (2009). Tourism attractions and their influences on handicraft employment in Isfahan (Master's thesis, Lulea University of Technology). Retrieved from http://epubl.ltu.se/1653-0187/2009/057/LTU-PBEX-09057-SE.pdf

Afrakhte, H. (2014). Rural geography of Iran. Tehran, Iran: Samt Publication.

Cappetta, R., Manzoni, B., \& Salvemini, S. (2010). Value drivers for cultural events: Empirical evidence from Italy. International Journal of Arts Management, 12(2), 4-16.

De Silver, G., \& Kundu, P. (2013). Handicraft products: Identify the factors that affecting the buying decision of customers (The viewpoints of Swedish shoppers). Unpublished Master’s Thesis, Umea School of Business and Economics. 
Dominique, R. (2008). Artesanía + Innovación la herramienta del futuro. Oportunidades de futuro (p. 21). Toledo, España: Fundación Española para la Innovación de la Artesanía.

El Economista. (2016). Repunta 5.7\% llegada de turismo a Chiapas. Retrieved from https://www.eleconomista.com.mx/estados/Repunta-5.7-llegada-de-turismo-a-Chiapas-20161124-0021.html

Export Promotion Council for Handicrafts [EPCH]. (2011). Craftcil Textiles India. Retrieved from http://www.epch.in/circulars/circulars/definition.pdf

Feng, T., Sun, L., \& Zhang, Y. (2010). The effects of customer and supplier involvement on competitive advantage: An empirical study in China. Industrial Marketing Management, 39(8), 1384-1394.

Mexico Destinos. (2017). Chiapas, México. Retrieved from https://www.mexicodestinos.com/chiapas/atracciones

National Institute of Statistics and Geography \& Secretariat of Culture. (2012). Las artesanías en la Encuesta Nacional de Consumo Cultural de México. Retrieved from https://www.gob.mx/cms/uploads/attachment/file/201779/Las_artesani_as_en_la_ENCCUM_con_imagen.pdf

Peteraf, M. A., \& Barney, J. B. (2003). Unraveling the resource-based tangle. Managerial and Decision Economics, 24(4), 309-323.

Ployhart, R. E., \& Donald, H. (2014). The fascinating psychological microfoundations of strategy and competitive advantage. Annual Review of Organizational Psychology and Organizational Behavior, 1, 145-172.

Porter, M. (1980). Competitive strategy. New York, NY: The Free Press.

Porter, M. E. (1990). The competitive advantage of nations (pp. 33-67). New York, NY: The Free Press.

Rodríguez, C. (2002). De artesanos locales a artesanos globales. ICE Económico, pp. 31-38.

Sánchez, J., Vargas, J. A., Mejía, J., Vázquez, G., \& Gaytán, J. (2013). The key factors to develop competitiveness. México: Ediciones de la noches.

Santos, J. C. (2008). Artesanía + Innovación la herramienta del futuro. Tendencias de evolución del mercado de artesanía (p. 19). Toledo, España: Fundación Española para la Innovación de la Artesanía.

Stronza, A. (2001). Anthropology of tourism: Forging new ground for ecotourism and other alternatives. Annual Review of Anthropology, 30, 261-283.

Tracey, M., Vonderembse, M. A., \& Lim, J. S. (1999). Manufacturing technology and strategy formulation: Keys to enhancing competitiveness and improving performance. Journal of Operations Management, 17(4), 411-428.

Turismo Chiapas. (2017). San Cristóbal de las Casas. Retrieved from http://www.turismochiapas.gob.mx/sectur/san-cristbal-de-las-casas-

Unión Chiapas. (2017). Chiapas espera crecimiento de 10\% en turismo para 2017. Retrieved from http://www.unionchiapas.mx/articulo/2017/02/10/turismo/chiapas-espera-crecimiento-de-10-en-turismo-para-2017

United Nations Educational, Scientific and Cultural Organization [UNESCO]. (2017). Crafts and design. UNESCO Regional Bureau for Education in Latin America and the Caribbean. Retrieved from http://www.unesco.org/new/en/santiago/culture/creative-industries/crafts-design/

World Tourism $\quad$ Organization. (2016). Boletín Turismo. $\quad$ Retrieved from http://www.concanaco.com.mx/wp-content/uploads/2016/boletines/Turismo-Enero-2016.pdf 